\title{
Carbon and nitrogen budget of the calanoid copepod Temora stylifera: effect of concentration and composition of food
}

\author{
Chantal Abou Debs*
}

Station Zoologique, Villefranche/mer, France

\begin{abstract}
The energy budget of Temora stylifera Dana, measured in $\mathrm{C}$ and $\mathrm{N}$ units, was determined for 2 phytoplanktonic diets and a range of concentrations. Excretion and respiration rates were strongly influenced by the type of food or its concentration after the second day. No maxima of rates of respiration or ingestion were achieved within the experimental range; maxima of faecal pellets and egg production were obtained at higher concentrations. Equations were developed to describe the pattern of response of each term of the budget to variations of food concentration. The difference between ingestion and expenses, ' $G$ ', was also evaluated for various concentrations; it did not seem to increase when food was in excess. Reasons for imbalance of the equation are discussed. The differential nutritive value could be attributed to differences in the 2 algal diets; although Phaedoactylum tricornutum seemed inadequate for good survival and reproduction of $T$. stylifera, Hymenomonas elongata covered all nutritonal needs at low cell concentrations.
\end{abstract}

\section{INTRODUCTION}

Small copepods such as Temora stylifera are very abundant in Mediterranean coastal waters in spring and autumn (Razouls, 1974). They play an important role in the transfer of organic matter from phytoplankton to higher trophic levels. To evaluate the availability of organic matter in the marine ecosystem, information on its pathways through one organism is needed. The different metabolic processes involved can be expressed in the budget equation: $G$ (growth or scope for growth) $=\mathrm{I}($ Ingestion) $-\mathrm{M}$ (Metabolism) $-\mathrm{P}$ (Reproduction) $-F($ Egestion). Copepods are assumed to be ammoniotelic and the losses of organic matter through metabolism of protein can be estimated in terms of nitrogen from the ammoniacal excretion. Carbon metabolism is estimated from respiration measurements.

Complete budgets in which all terms of the equation have been measured were presented for fish (Solomon and Brafield, 1972; Elliott, 1976), and sea urchins (Miller and Mann, 1973; Greenwood, 1980). In most copepod studies, ingestion or assimilation were esti-

- Present address: Marine Ecology Laboratory, Bedford Institute of Oceanography Dartmouth, Nova Scotia, Canada mated in terms of differences from an equation assumed to be balanced (Corner et al., 1967; Harris, 1973; Gaudy, 1974); other terms, such as reproduction, were sometimes neglected (Fernandez, 1978; Copping and Lorenzen, 1980; Vidal, 1980). Furthermore, metabolic activity is often measured on non-feeding animals which may have rapidly decreasing levels of metabolic activity (Nival et al., 1974; Ikeda, 1977). Ingestion has been shown to vary with composition and concentration of food (Frost, 1972; Gaudy, 1974). The same type of variation occurs in egg production and faecal pellet production (Nassogne, 1970; Abou Debs, 1979; Abou Debs and Nival, 1983).

The aim of this study is: (1) to establish a carbon and nitrogen budget for Temora stylifera by measuring all the terms under similar conditions; (2) to assess the effect of the concentration and the composition of food on all the terms including metabolism.

\section{METHODS}

Adult Temora stylifera were collected in the Bay of Villefranche-sur-mer, France, by oblique tows between $50 \mathrm{~m}$ and surface, with a $690 \mu \mathrm{m}$ mesh net. One to $2 \mathrm{~h}$ later, copepods were rapidly sorted and 


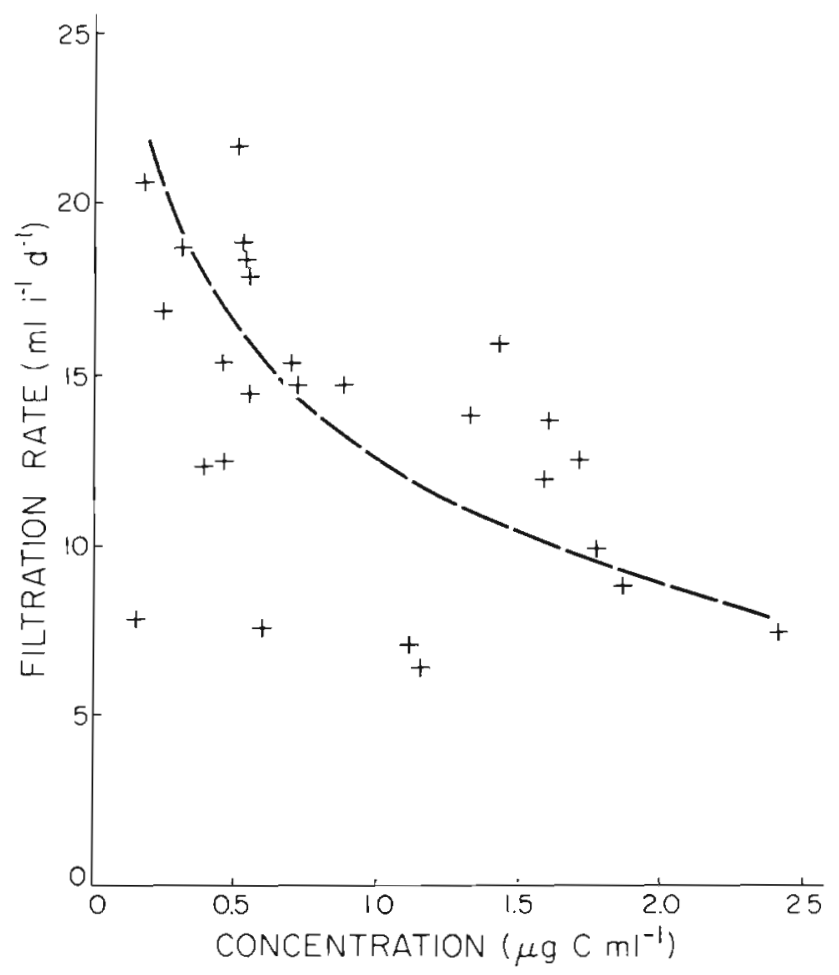

Fig. 1. Temora stylifera. Filtration rate $\left(F_{j}\right)$ of individuals feeding on different concentrations of Hymenomonas elongata

acclimated for 12 to $24 \mathrm{~h}$ to experimental conditions at $16^{\circ} \mathrm{C}$ (mean temperature in spring and autumn in the sea; Nival and Corre, 1976) under natural light conditions supplied through a window.

During ingestion experiments, copepods were fed either Hymenomonas elongata (Haptophycae), $13 \mu \mathrm{m}$ in width, at a concentration range of 1 to $8 \times 10^{3}$ cells $\mathrm{ml}^{-1}$ or Phaeodactylum tricornutum (Bacillariophycae), in the triradiate form; dimensions: 4 and $8 \mu \mathrm{m}$, at
50 and $100 \times 10^{3}$ cells $\mathrm{ml}^{-1}$. The algae were grown in semi-continuous cultures, with $2 \%$ E.S. Provasoli medium (Provasoli, 1966) at $16^{\circ} \mathrm{C}$. Fifty and 80 copepods were added to 500 and $800 \mathrm{ml}$ of algal suspension. Control beakers were prepared the same way omitting the copepods. Algal concentrations were monitored by 2 methods detailed in Abou Debs (1979): (1) every 6 to $12 \mathrm{~h}$ over 1 full day, using a Coulter counter to measure the particle concentrations; (2) every 30 min over 2 to $3 \mathrm{~h}$ using a scintillation spectrometer to measure the concentration of carbon-14 in the labelled food. When concentrations became too low for precise counts with the Coulter Counter (Sheldon and Parsons, 1967), copepods were placed in new algal suspensions adjusted to the initial concentrations.

Phytoplankton growth in the controls $(\mathrm{k}=1 / \mathrm{t} \ln \mathrm{B} /$ $\left.\mathrm{B}_{\mathrm{o}}\right)$ and the decrease $\left(\mathrm{K}=1 / \mathrm{t} \ln \mathrm{B}^{\prime} / \mathrm{B}_{\mathrm{o}}{ }^{\prime}\right)$ in the experimental beakers were both exponential (Abou Debs, 1979). $B_{0}$ and $B_{0}^{\prime}$ are initial algal concentrations and $B$ and $B^{\prime}$ are final concentrations in respective beakers. Filtration rate $(F)$ could then be calculated from the difference between the 2 rates: $F=(\mathrm{k}-\mathrm{K}) \times \mathrm{v} / \mathrm{N}$, where $\mathrm{N}=$ numbers of individuals; $\mathrm{v}=$ total volume of suspension. Ingestion rate was the product of filtration rate times the mean concentration $(I=F \times \bar{C})$, and was expressed as $\mu \mathrm{g}$ carbon and $\mu \mathrm{g}$ nitrogen individual $^{-1} \mathrm{~d}^{-1}$ using for each algae values previously determined with a Perkin-Elmer analyser (Table 1).

Measurements of oxygen utilization were made on copepods kept for 2 to $8 \mathrm{~d}$ in $0.22 \mu \mathrm{m}$ Millipore filtered sea water to give a 'standard rate' and also on copepods fed known concentrations of algae before and during the experiments to give an active metabolic rate. Concentrations were adjusted to $1,2,4$ and $8 \times 10^{3}$ cells $\mathrm{ml}^{-1}$ of Hymenomonas elongata and $100 \times 10^{3}$ cells $\mathrm{ml}^{-1}$ of Phaeodactylum tricornutum.

Table 1. Temora stylifera. Physical and elementary chemical composition of the phytoplankton utilized and of eggs and faecal pellets produced by individuals feeding on Hymenomonas elongata. Bracketed \% values: standard deviation; \pm confidence interval at $\mathrm{P}=0.05$. $\mathrm{D}$ : diameter for spherical shapes and $\mathrm{L} / \mathrm{l}$ : length or diameter over width

\begin{tabular}{|c|c|c|c|c|c|c|c|c|c|}
\hline \multirow[t]{2}{*}{ Material } & & \multirow{2}{*}{$\begin{array}{l}\text { Size } \\
(\mu \mathrm{m})\end{array}$} & \multirow{2}{*}{$\begin{array}{l}\text { Volume } \\
\left(\mu \mathrm{m}^{3}\right)\end{array}$} & \multirow{2}{*}{$\begin{array}{c}\text { Dry weight } \\
(\mu g)\end{array}$} & \multicolumn{2}{|c|}{ Carbon } & \multicolumn{2}{|c|}{ Nitrogen } & \multirow[t]{2}{*}{$\mathrm{C} / \mathrm{N}$} \\
\hline & & & & & $\left(\mu g C\right.$ ind.$\left.^{-1}\right)$ & $\left(\mu g C \mu \mathrm{m}^{-3}\right)$ & $\left(\mu g N\right.$ ind. $\left.{ }^{-1}\right)$ & $\left(\mu \mathrm{gN} \mu \mathrm{m}^{-3}\right)$ & \\
\hline $\begin{array}{l}\text { Hymenomonas } \\
\text { elongata }\end{array}$ & $\mathrm{D}$ & $\begin{array}{c}13.1 \\
(15 \%)\end{array}$ & $\begin{array}{c}798 \\
(11 \%)\end{array}$ & & $\begin{array}{l}585.7 \\
\pm 106.0\end{array}$ & 73.39 & $\begin{array}{l}60.0 \\
\pm 10.0\end{array}$ & 7.52 & 9.77 \\
\hline \multirow[t]{2}{*}{$\begin{array}{l}\text { Phaedactylum } \\
\text { tricornutum }\end{array}$} & $\mathrm{L} / \mathrm{l}$ & $\begin{array}{c}14.09 / 4.3 \\
(10 \%)\end{array}$ & $\begin{array}{c}59 \\
(10 \%)\end{array}$ & & $\begin{array}{c}8.4 \\
\pm 0.69\end{array}$ & 14.24 & $\begin{array}{l}1.40 \\
\pm 0.04\end{array}$ & 2.37 & 6.00 \\
\hline & & & & & & $\mu \mathrm{gC} / \mu \mathrm{g}$ & & $\mu \mathrm{gN} / \mu \mathrm{g}$ & \\
\hline \multirow[t]{2}{*}{$\begin{array}{l}\text { Faecal } \\
\text { pellets }\end{array}$} & $\mathrm{L} / 1$ & $\begin{array}{l}221 / 56.0 \\
\pm 31.1 / 6.0\end{array}$ & $3.6 \times 10^{5}$ & 2.32 & 0.154 & & 0.018 & & 8.29 \\
\hline & & & & & & $\mu \mathrm{gC} / \mu \mathrm{g}$ & & $\mu \mathrm{gN} / \mu \mathrm{g}$ & \\
\hline Eggs & $D$ & $\begin{array}{c}80.49 \\
\pm 18.18\end{array}$ & $\begin{array}{l}6.78 \\
\pm 0.34\end{array}$ & $\begin{array}{l}0.57 \\
\pm 0.08\end{array}$ & $\begin{array}{r}0.0594 \\
\pm 0.071\end{array}$ & 92.55 & $\begin{array}{c}0.0060 \\
\pm 0.0018\end{array}$ & 7.71 & 10.37 \\
\hline
\end{tabular}


Twenty-five to 50 copepods were added to $250 \mathrm{ml}$ of sea water or culture of known oxygen content and monitored for oxygen after $24 \mathrm{~h}$ with an IL125S Polarographic electrode. Changes in controls with and without algae were also measured. Respiration rates were given in $\mu \mathrm{l} \mathrm{O}_{2}$ individual ${ }^{-1} \mathrm{~h}^{-1}$ after correction for changes in appropriate controls. Carbon requirements were estimated from respiration rates assuming an R. Q. $=1$.

Excretion was determined on alternate days from the measurements of respiration rate, over the same $6 \mathrm{~d}$ period, with the population of copepods maintained at 2 levels of food concentration between the sampling: $4 \times 10^{3}$ cells $\mathrm{ml}^{-1}$ of Hymenomonas elongata or $100 \times 10^{3}$ cells $\mathrm{ml}^{-1}$ of Phaeodactylum tricornutum.

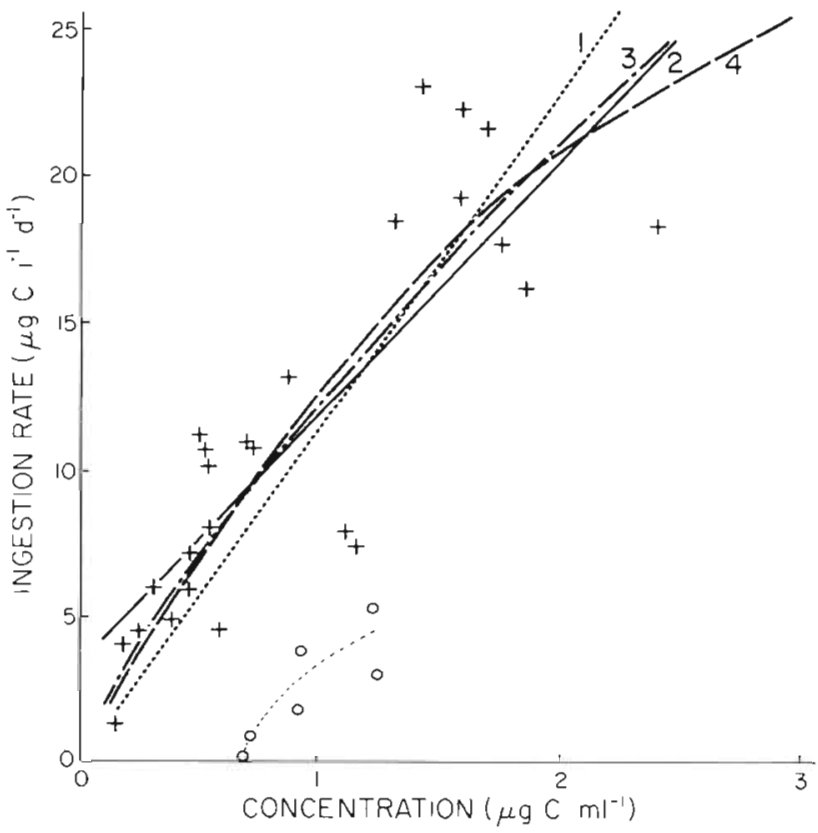

Fig. 2. Temora stylifera. Ingestion rate of individuals feeding on different concentrations of Hymenomonas elongata $(+)$ and Phaeodactylum tricornutum (o). Regressions: 1 : $1=$ $11.05 \mathrm{~B}$ ( $\mathrm{n}=27 ; \mathrm{F}=37.22 ; \mathrm{P}<0.001) ; 2: \mathrm{I}=8.53 \mathrm{~B}+3.03$ $(\mathrm{n}=27 ; \mathrm{F}=53.69 ; \mathrm{P}<0.001) ; 3 ; \mathrm{I}=11.892 \times \mathrm{B}^{0.785}(\mathrm{n}=27$; $F=55.105 ; \quad P<0.001) ; 4: I=32.89\left(1-e^{-0.48 B}\right) \quad(n=27 ;$ $\mathrm{F}=58.76 ; \mathrm{P}<0.001$ ) (curve fitted after extrapolation, see text). $F$, values for the test $F$
Some additional samples were also analysed after $26 \mathrm{~d}$. The copepods were kept in filtered sea water during an incubation period of $6 \mathrm{~h}$ and a sample taken every $1 / 2$ or $1 \mathrm{~h}$. Measurements were made in $250 \mathrm{ml}$ flasks with 50 individuals in filtered sea water. Measurements were also made with starved copepods kept in filtered sea water over the whole $6 \mathrm{~d}$ period to give a 'standard rate'. Ammonia concentration was measured with the Technicon II Autoanalyser. Excretion rates were calculated from the slope of the regression between ammonia concentration and time (Abou Debs, 1979) and expressed in $\mu \mathrm{gN}$ individual ${ }^{-1} \mathrm{~d}^{-1}$.

Eggs and faecal pellets produced by copepods maintained in individual containers with $100 \mathrm{ml}$ of food suspension were counted and removed for chemical analysis every $24 \mathrm{~h}$ during 7 to 15 consecutive days. The food suspension was adjusted to the different initial concentrations of Hymenomonas elongata (1, 4, $8,16,32$ and $64 \times 10^{3}$ cells $\mathrm{ml}^{-1}$ ) or Phaeodactylum tricornutum $\left(1,10,25,50\right.$ and $100 \times 10^{3}$ cells $\left.\mathrm{ml}^{-1}\right)$ and renewed every day. Some copepods were kept in filtered sea water without food as controls. More details about the methodology and the results are given in Abou Debs and Nival (1983).

\section{RESULTS}

\section{Ingestion}

The filtration rate of Temora stylifera decreased significantly $(\mathrm{P}<0.05)$ with increasing concentration of Hymenomonas elongata. Coulter counting and carbon 14 method gave similar grazing estimates $(P<0.05$; Abou Debs, 1979) as was also observed by Hargis (1977). All data were therefore pooled and a significant $(P<0.05)$ regression was obtained in spite of a large scatter in the data. Ingestion rate (I) increased continuously with concentration (B); the relationship could be described equally well with several mathematical equations all highly significant $(P<0.001$ ) (see also Mullin et al., 1975). There was no evidence of maximum ingestion rate or plateau, up to the highest concentration used here (Fig. 2).

Table 2. Temora stylifera. Parameters of the regression $\mathrm{Y}=\mathrm{Y} \max \left(\mathrm{l}-\mathrm{e}^{-\mathrm{bx}}\right)+\mathrm{c}$ describing the relation between egg production or egestion and the concentration of Hymenomonas elongata

\begin{tabular}{|c|c|c|c|c|c|c|c|c|c|c|c|}
\hline \multirow{2}{*}{$\begin{array}{c}\text { Unity } \\
\text { Parameter }\end{array}$} & \multicolumn{3}{|c|}{$\begin{array}{l}\text { Number eggs or faecal } \\
\text { pellets } \mathrm{i}^{-1} \mathrm{~d}^{-1}\end{array}$} & \multicolumn{3}{|c|}{$\mu \mathrm{gCi}^{-1} \mathrm{~d}^{-1}$} & \multicolumn{3}{|c|}{$\mu \mathrm{gNi}^{-1} \mathrm{~d}^{-1}$} & \multirow[b]{2}{*}{ n. of item } & \multirow[b]{2}{*}{$P$} \\
\hline & $Y \max$ & $\mathrm{b}$ & c & $Y \max$ & $\mathrm{b}$ & c & $Y \max$ & $\mathrm{b}$ & c & & \\
\hline Egg production $(\mathrm{P})$ & 278.45 & 0.239 & 15.17 & 16.54 & 0.405 & 0.90 & 1.67 & 3.98 & 0.09 & $9^{\circ}$ & 0.001 \\
\hline Egestion $(F)$ & 61.96 & 0.285 & - & 9.54 & 0.483 & - & 1.19 & 4.75 & - & 13 & 0.001 \\
\hline
\end{tabular}


With Phaeodactylum tricornutum suspensions, ingestion rate in terms of carbon and nitrogen was very low compared to that for Hymenomonas elongata (Fig. 2) even with an initially greater concentration of $10^{5}$ cells $\mathrm{ml}^{-1}$.

\section{Egg production and egestion}

Egg production and egestion are both related to the concentration of Hymenomonas elongata by a negative exponential curve (Abou Debs, 1979; Abou Debs and Nival, 1983). Egg production and egestion followed the same pattern and the exponential parameters of these equations were similar (Table 2). Maximal production of eggs reached $277 \pm 20$ eggs female ${ }^{-1} 7 \mathrm{~d}^{-1}$ (Abou Debs and Nival, 1983) at $H$. elongata concentrations ranging from 8 to $64 \times 10^{3}$ cells $\mathrm{ml}^{-1}$, and that for faecal pellets reached $60.5 \pm 6.7$ copepod $^{-1} \mathrm{~d}^{-1}$ at 16 to $64 \times 10^{3}$ cells $\mathrm{ml}^{-1}$. The production of eggs was much lower in the presence of Phaeodactylum tricornutum, even at the highest concentrations: 47 to 60 eggs female $\mathrm{f}^{-1} 7 \mathrm{~d}^{-1}$, associated with a negligible egestion rate.

A highly significant linear regression, was fitted between egestion ( $\mathrm{Y}$ ) and ingestion rate (X) on Hymenomonas elongata by Temora stylifera, when both were measured under similar conditions of food and temperature:

$$
\begin{aligned}
& \mathrm{Y}=\mathrm{a} X+\mathrm{b} \\
& \mathrm{a}=0.29 \pm 0.04 ; \mathrm{b}=-0.134 \pm 0.68 \\
& \mathrm{n}=5 ; \mathrm{r}^{2}=0.98 ; \mathrm{P}<0.001
\end{aligned}
$$

where $Y$ and $X$ are in $\mu g \mathrm{Ci}^{-1} \mathrm{~d}^{-1}$. Zero was enclosed by the confidence interval of the ordinate intercept. Ingestion rate was then calculated at higher concentrations with the above model from egestion measurements. A new model was fitted for ingestion rate versus concentration and it yielded a maximal ingestion rate at the highest concentrations of $H$. elongata. The exponential part of that model fitted our experimental data as well as the first one as shown in Fig. 2 (test $F$; $\mathrm{P}<0.001$ ). That model will be used in the budget equation.

\section{Respiration}

Respiration rate of starved copepods decreased rapidly reaching one third of the initial value in $3 \mathrm{~d}$ (Fig. 3); however, due to the high rate of mortality, the measurements had to be discontinued. The significant decrease $(P<0.05)$ of respiration rate $(R)$ with starvation ( $t$ ) could be described by an exponential relation and compared to a similar relation given by Nival et al. (1974) for Temora stylifera from the Morocco upwel-

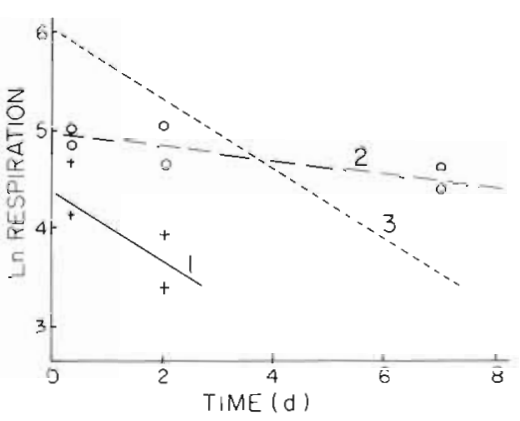

Fig. 3. Temora stylifera. Log respiration rate of individuals measured as $10^{3} \mu \mathrm{l} \mathrm{O}_{2} \mathrm{i}^{-1} \mathrm{~h}^{-1}$ against duration of experirment. 1: unfed copepods: $\mathrm{R}=83.10 \times \mathrm{e}^{-0.0105 t} ; 2$ : copepods feeding on Hymenomonas elongata $\left(3-4\right.$ cells $\left.\mathrm{ml}^{-1}\right): \mathrm{R}=142.59 \times$ $\mathrm{e}^{-0.003 \mathrm{t}}, 3$ : unfed copepods from the Morocco upwelling (from Nival et al. 1974): $R=430 \times \mathrm{e}^{-0014 t}$

ling area. Initial standard metabolism was higher for South Atlantic copepods, perhaps related to their different geographic origin or to a higher primary production level in their environment but the rate of decrease was very similar (Fig. 3). Copepods maintained with Hymenomonas elongata $\left(4.10^{3}\right.$ cells $\left.\mathrm{ml}^{-1}\right)$ between the measurements showed a slow but non-significant decrease $(P<0.05)$ in their metabolic rate over $8 \mathrm{~d}$ (Fig. 3).

When concentration of Hymenomonas elongata, offered before and during the measurements, increased from 1 to $8 \times 10^{3}$ cells $\mathrm{mi}^{-1}$, respiration rate also increased significantly $(P<0.05)$. Three successive experiments, repeated every $48 \mathrm{~h}$ on the same population of copepods, were not different (Fig. 4) $\mathrm{P}<0.05$ (comparison of regression by an F test; Soka] and Rohlf, 1969); the data were pooled. After normali-

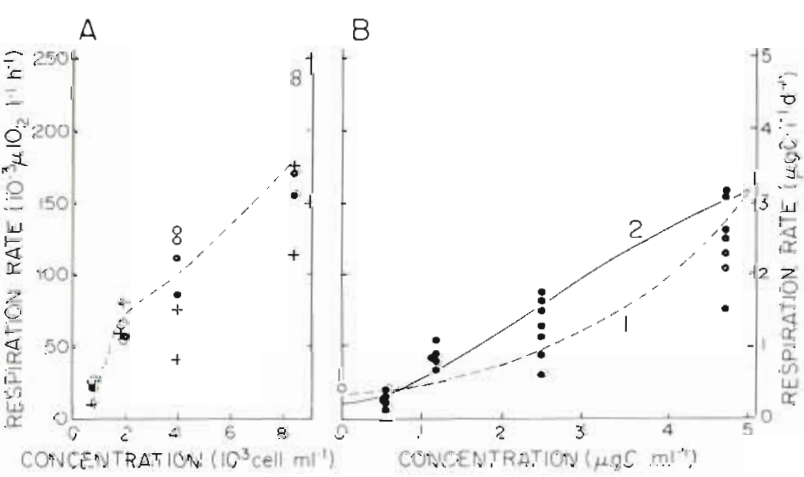

Fig. 4. Temora stylifera. Respiration rate (R) of individuals feeding on different concentrations of Hymenomonas elongata before and during the measurements and over $6 \mathrm{~d}$ : Day $2(+)$, Day $4(0)$, Day $6(\bullet)$. A: respiration rate measured in $10^{3}$ $\mu \mathrm{l} \mathrm{O}_{2} \mathrm{i}^{-1} \mathrm{~h}^{-1}$ and $\mathrm{B}$, in $10^{3}$ cells $\mathrm{ml}^{-1}$ B: respiration rate in $\mu \mathrm{g}$ $\mathrm{Ci}^{-1} \mathrm{~d}^{-1}$ and $\mathrm{B}$ in $\mu \mathrm{g} \mathrm{C} \mathrm{ml} \mathrm{Cl}^{-1}$ : regression curve $\mathrm{R}=25.279 \times$ $1.301^{\mathrm{B}}\left(\mathrm{n}=21 ; \mathrm{r}^{2}=0.80 ; \mathrm{P}<0.001\right) ; 2$ : curve fitted after extrapolation (see text) $\mathrm{R}=0.14 \exp 3.31\left(\mathrm{l}-\mathrm{e}^{-048 \mathrm{~B}}\right)$ $(\mathrm{P}<0.001)$; standard rate $(0)$ have been measured in a previous experiment 
zation and homogenization of the variances by means of a semi-logarithmic transformation (test of Bartlett, $\mathrm{P}<0.05$ ) the resulting equations between respiration rate $(\mathrm{Y})$ and concentration of $H$. elongata $(\mathrm{X})$ can be written as; in terms of oxygen

$$
\begin{aligned}
& Y=25.279 \times 1.301^{x} \\
& n=21 ; r^{2}=0.80 ; Y=10^{3} \mu l 0^{2} i^{-1} d^{-1} \\
& X=10^{3} \text { cells } \cdot \mathrm{ml}^{-1}
\end{aligned}
$$

or in terms of carbon:

$$
\begin{aligned}
& Y=0.329 \times 1.301^{X / 0.59} \\
& Y=\mu \mathrm{gCi}^{-1} \mathrm{~d}^{-1} ; \mathrm{X}=\mu \mathrm{gCml}^{-1}
\end{aligned}
$$

The calculated value at the ordinale intercept (Fig. 4) agreed well with earlier measurements of the standard respiration rate. An 8 -fold increase in food concentration resulted in a 9-fold increase in respiration rate. This experiment was run for $6 d$ to be certain that the effect of nutritional activity on respiration rate was not confounded with the effects of experimental stress. Such an increase of respiration rate is probably related to the energy cost of capturing, ingesting, digesting and transforming larger amounts of food.

An exponential relation can be fitted between ingestion rate $(X)$ and respiration rate $(Y)$ measured under similar conditions of food and temperature.

$$
\begin{aligned}
& \mathrm{Y}=0.329 \times 1.301^{(0.15 \mathrm{X})} \\
& \mathrm{n}=6 ; \mathrm{r}^{2}=0.90 \\
& \mathrm{X} \text { and } \mathrm{Y} \text { in } \mu \mathrm{gCi}^{-1} \mathrm{~d}^{-1}
\end{aligned}
$$

This relation and the equation shown in Table 2 , yielded an exponential model for respiration versus concentration of Hymenomonas elongata given in Fig. 4. The value of respiration rate at the ordinal intercept $\left(\mathrm{R}=0.54 \mu \mathrm{l} 0_{2} \mathrm{i}^{-1} \mathrm{~d}^{-1}\right.$ or $\left.0.145 \mu \mathrm{gCi}^{-1} \mathrm{~d}^{-1}\right)$ agreed well with the experimental standard rate, and, in the exponential part of the curve, the experimental data fitted also the new model ( $F$ test; $P<0.001$ ). At high concentrations of food, a maximal respiration rate

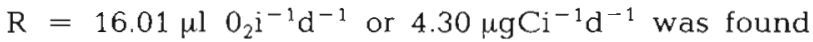
which correspond reasonable with the estimated maximal ingestion rate.

\section{Excretion}

An increase in ammoniacal excretion rate occurred during the first day (Fig. 5) when Temora stylifera was fed either Hymenomonas elongata $\left(4.10^{3} \mathrm{cells}^{-1}\right)$ or Phaeodactylum tricornutum $\left(100.10^{3}\right.$ cells $\left.\mathrm{ml}^{-1}\right)$. Such an increase had also been observed by Mayzaud (1976) and Ikeda (1977) for various species of copepods and euphausiids which they attributed to short-term experimental stress. After acclimation, and over a longer experimental period of 6 or $20 \mathrm{~d}$, the copepods showed a more constant excretion rate. The values for
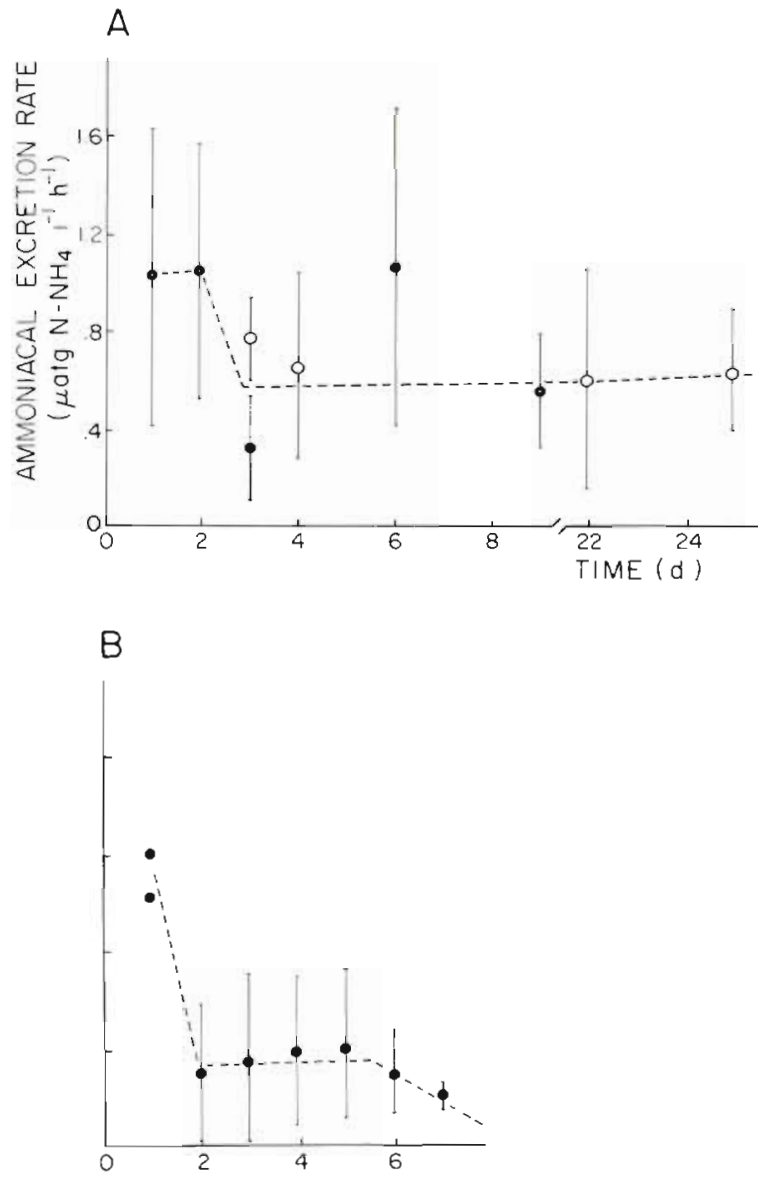

Fig. 5. Temora stylifera. Ammoniacal excretion rate (E) of individuals plotted against duration of experiment. A: copepods fed Hymenomonas elongata (3-4 $10^{3}$ cells ml ${ }^{-1}$ ); B: copepods fed Phaeodactylum tricornutum $\left(10010^{3}\right.$ cells $\mathrm{ml}^{-1} \mathrm{j}$; experiments conducted on 6.4.76; 0 experiments conducted on 26.4 .76

the first $2 \mathrm{~d}$ were not taken into account in the comparison of the excretion rates of Temora maintained with 2 different diets. Mean ammonia excretion rate with $P$. triconutum $\left(\mathrm{E}=0.32 \pm 0.00510^{3} \mu \mathrm{g}\right.$ at $\mathrm{N}$ $\mathrm{NH} 4 \mathrm{i}^{-1} \mathbf{h}^{-1}$ ) was significantly lower (one way Anova, $\mathrm{P}<0.05)$ than that with $H$. elongata $(\mathrm{E}=0.68 \pm 0.20$ $10^{3} \mu \mathrm{g}$ at $\mathrm{N}-\mathrm{NH} 4 \mathrm{i}^{-1} \mathrm{~h}^{-1}$ ). A drop in the excretion rate of $T$. stylifera occurred after $5 \mathrm{~d}$, feeding on $P$. tricornutum accompanied by a high mortality, suggesting deterioration in the copepod's condition. The constant excretion rate and good survival obtained with $H$. elongata confirmed the suitability of that diet for $T$. stylifera.

\section{Assimilation}

Assimilation rate can be calculated according to the formula: $\mathrm{A}=([\mathrm{I}-\mathrm{F}] / \mathrm{I}) \times 100$, where $\mathrm{A}, \mathrm{I}$ and $\mathrm{F}$ were expressed in $\mu \mathrm{gN}$ or $\mu \mathrm{gCi}^{-1} \mathrm{~d}^{-1}$. Each term was 


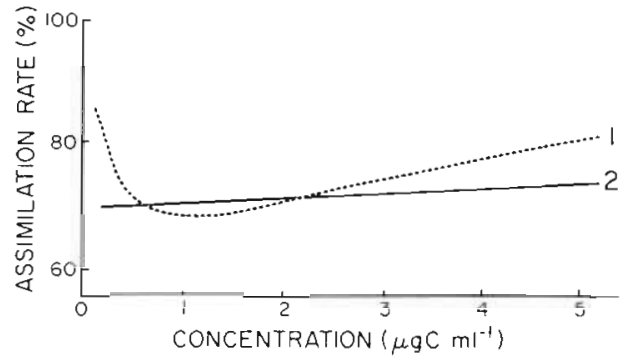

Fig. 6. Temora stylifera. Variation of assimilation rate of individuals feeding on Hymenomonas elongata with concentration $(B) . I: A=\left(9.54 \mathrm{e}^{-0.48 B}+8.53 \mathrm{~B}-6.24\right) /(8.53 \mathrm{~B}+3.30) ; 2$ :

$$
A=0.71
$$

replaced by its equation versus concentration, and it was then possible to calculate an equation relating assimilation rate with concentration of Hymenomonas elongata (Fig. 6). The response of the assimilation rate to an increase in concentration was different depending on whether a rectilinear or a curvilinear model was assumed for ingestion. In the first case, an initial decrease in assimilation rate was followed by a slow increase in the range of 69 to $80 \%$. In the second case, ingestion and egestion had the same exponential coefficient which yielded a constant assimilation rate independent of the concentration of food: in terms of carbon $A_{c}=72 \%$ and in terms of nitrogen $A_{n}=69 \%$.

With Phaeodactylum tricornutum, assimilation rate was also high: $\mathrm{A}=70 \%$. Ingestion rate was low but losses by egestion were negligible. There was thus no evidence of effect of amount or quality of food on assimilation rate.

\section{Budget in terms of carbon}

All elements of the budget, I, F, R, P, were calculated in terms of carbon. The difference between ingested carbon and carbon lost in metabolic activity, egg production and egestion was calculated by substituting for each term in the global equation: $G=I-(F+R+P)$, the function describing its relationship to food. Egg production, measured over $7 \mathrm{~d}$ (Abou Debs and Nival, 1983), could be expressed as the mean production per day: $\overline{\mathrm{P}}=\mathrm{P} / 7$, or as the production of the first day: $\mathrm{P}_{\max }$ $=28 \%$ P. $\bar{P}$ was used in the following equation:

Table 3. Temora stylifera. Budget in carbon of individuals feeding on Hymenomonas elongata and Phaeodactylum tricomutum

\begin{tabular}{|c|c|c|c|c|c|c|c|c|c|}
\hline \multicolumn{3}{|c|}{ Algal species: $H$. elongata } & \multicolumn{4}{|c|}{$\mathrm{G}_{\mathrm{c}^{\prime}} \mathrm{I}_{\mathrm{c}^{\prime}} \mathrm{R}_{\mathrm{c}}, \mathrm{F}_{\mathrm{c}^{\prime}} \overline{\mathrm{P}}_{\mathrm{c}^{\prime}} \mathrm{P}_{\mathrm{c}} \max : \mu \mathrm{gCi}^{-1} \mathrm{~d}^{-1}$} & \multicolumn{3}{|c|}{$\mathrm{G}_{\mathrm{c}}=\mathrm{I}_{\mathrm{c}}-\left(\mathrm{F}_{\mathrm{c}}+\mathrm{R}_{\mathrm{c}}+\overline{\mathrm{P}}_{\mathrm{c}}\right)$} \\
\hline $\begin{array}{l}\text { Concentration } \\
\text { cells } \mathrm{ml}^{-1}\end{array}$ & $\frac{\left(\mathrm{B}_{\mathrm{c}}\right)}{\mu \mathrm{gCm} l^{-1}}$ & $\begin{array}{l}\text { Ingestion } \\
\text { (Id) }\end{array}$ & $\begin{array}{l}\text { Egestion } \\
\qquad\left(F_{c}\right)\end{array}$ & $\begin{array}{c}\text { Respiration } \\
\left(R_{c}\right)\end{array}$ & $\underset{\left(\bar{P}_{c}\right)}{\operatorname{Egg} P}$ & $\begin{array}{l}\text { uction } \\
\left(P_{c} \max \right)\end{array}$ & $\begin{array}{c}\text { Expenses } \\
\left(\mathrm{F}_{\mathrm{c}}+\mathrm{R}_{\mathrm{c}}+\overline{\mathrm{P}}\right)\end{array}$ & $\mathrm{G}_{\mathrm{c}}$ & $G_{c} / I_{c}$ \\
\hline 0 & 0 & & & 0.14 & & & 0.14 & -0.14 & \\
\hline 1000 & 0.59 & 8.11 & 2.35 & 0.32 & 0.50 & 0.98 & 3.17 & 4.94 & 0.60 \\
\hline 2000 & 1.18 & 14.22 & 4.13 & 0.58 & 0.90 & 1.76 & 5.61 & 8.61 & 0.60 \\
\hline 4000 & 2.36 & 22.29 & 6.48 & 1.32 & 1.45 & 2.85 & 9.25 & 13.04 & 0.58 \\
\hline 8000 & 4.72 & 29.48 & 8.56 & 2.72 & 2.01 & 3.94 & 13.29 & 16.19 & 0.55 \\
\hline 16000 & 9.44 & 32.53 & 9.44 & 3.70 & 2.36 & 4.62 & 15.50 & 17.03 & 0.52 \\
\hline 32000 & 18.88 & 32.89 & 9.54 & 3.83 & 2.36 & 4.62 & 15.75 & 17.15 & 0.52 \\
\hline 64000 & 27.76 & 32.89 & 9.54 & 3.83 & 2.36 & 4.62 & 15.73 & 17.15 & 0.52 \\
\hline \multicolumn{10}{|c|}{ Assimilation $\left(\mathrm{A}_{c}\right)=0.71$} \\
\hline \multirow{8}{*}{$\begin{array}{r}0 \\
1000 \\
2000 \\
4000 \\
8000 \\
16000 \\
32000 \\
64000\end{array}$} & 0 & & & $0.43 \neq$ & & & & & \\
\hline & 0.59 & $8.33^{\circ}$ & & 0.26 & 0.45 & 0.88 & & & \\
\hline & 1.18 & $13.3^{\circ}$ & & 0.83 & 0.75 & 1.46 & & & \\
\hline & 2.36 & $23.43^{\circ}$ & 6.53 & 1.23 & 1.71 & 3.36 & & & \\
\hline & 4.72 & & & 2.40 & 2.27 & 4.45 & & & \\
\hline & 9.44 & & 9.04 & & 2.26 & 4.42 & & & \\
\hline & 18.88 & & 10.29 & & 2.80 & 5.49 & & & \\
\hline & 27.76 & & 9.15 & & 2.23 & 4.38 & & & \\
\hline \multicolumn{10}{|c|}{ Algal species: $P$. tricornutum } \\
\hline 100,000 & 0.80 & 1.26 & 0.26 & 0.34 & 0.49 & 0.96 & 1.09 & 0.17 & 0.13 \\
\hline \multicolumn{10}{|c|}{ Assimilation $\left(A_{c}\right)=0.80$} \\
\hline \multicolumn{10}{|c|}{$\begin{array}{l}\text { (a) Values calculated from equations fitted on experimental data: } I_{c} \cdot=8.53 B_{c}+3.30 ; F_{c}=9.54\left(1-e^{-0.48 B_{c}}\right) ; \bar{P}_{c}=2.36 \\
\left(1-e^{-0405 B_{c}}\right) \text {, and from equations including extrapolated values for high food concentrations: } I_{c}=32.89\left(1-e^{-0.48 B_{c}}\right) ; R_{c}=0.14 \\
\text { exp } 3.31\left(l-e^{-0.48 B_{c}}\right) \\
\text { (b) Experimental data are shown for comparison (Abou Debs, } 1979) \\
\text { f Standard respiration was measured in a separate experiment. } \bar{P}=\text { total } \mathrm{P} / 7 \text { and Pmax }=28 \% \mathrm{P} \text { total (Abou Debs, } 1979 ; \\
\text { Abou Debs and Nival, 1983) }\end{array}$} \\
\hline
\end{tabular}




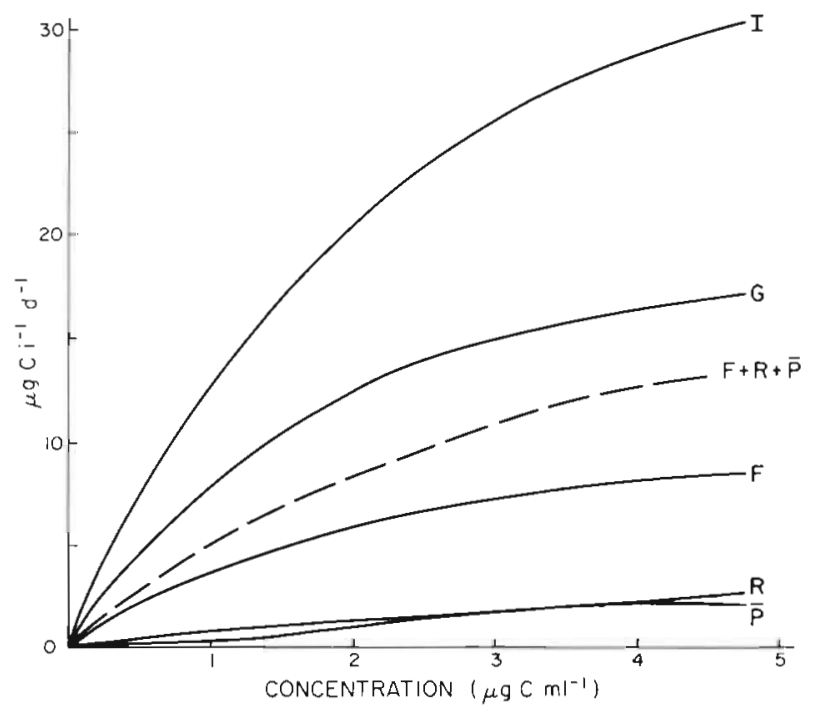

Fig. 7. Temora stylifera. Carbon budget of individuals. Each term is plotted against concentration of Hymenomonas elongata. $\mathrm{G}_{\mathrm{c}}=\mathrm{I}_{\mathrm{c}}-\left(\mathrm{F}_{\mathrm{c}}+\mathrm{R}_{\mathrm{c}}+\mathrm{P}_{\mathrm{c}}\right) ; \mathrm{P}=\overline{\mathrm{P}}$ (see text). Equations given in Table 3

$G=32.89\left(1-\exp ^{-0.48 B}\right)-\left(9.54\left[1-\exp ^{-0.48 B}\right]+2.36[1-\right.$ $\left.\left.\exp ^{-0.40 B}\right]+0.14 \exp 3.31\left[1-x^{0.48 B}\right]\right)-$ with G: $\mu \mathrm{gCi}^{-1} \mathrm{~d}^{-1}$ and $\mathrm{B}: \mu \mathrm{gC} \mathrm{ml}^{-1}$.

With Hymenomonas elongata, ingestion in carbon stayed higher than the carbon required for maintenance and reproduction (Table 3 ). When concentration increased, $G$ could also be described by a negative exponential curve (Fig. 7). Ingestion seemed to be about twice the losses at all food concentrations. G was proportional to concentration in the experimental range and became independent for high values of $B$. By using the same exponential term, a simplification was introduced in the budget equation which accounted for $2 \%$ error in $\mathrm{G}$ at $\mathrm{B}=1 \mu \mathrm{gC} \mathrm{ml}^{-1}$ and $0.2 \%$ at $\mathrm{B}=5 \mu \mathrm{gC} \mathrm{m}{ }^{-1}$ yielding:

$G=20.99\left(1-\exp ^{-0.48 B}\right)-0.14 \exp 3.31\left(1-\exp ^{-0.48 B}\right)$

When the diet was composed of Phaeodactylum tricornutum, even at highest concentrations, containing as much carbon as 1.3 cells $\mathrm{ml}^{-1}$ Hymenomonas elongata, copepods behaved as if starved, reducing their metabolism, egg production and egestion. Moreover, ingestion was too low to meet basal metabolism and $G$ approached zero.

\section{Budget in terms of nitrogen}

A similar procedure was followed to set up the nitrogen budget. Metabolism was expressed as ammonia excretion and all the terms were measured in $\mu \mathrm{gNi}^{-1}$ $\mathrm{d}^{-1}$. G was always positive when the diet was composed of Hymenomonas elongata and negative in both starved and those feeding on Phaeodactylum tricornutum (Table 4). The proportion of nitrogen provided by the food was lower than that of carbon (Tables 3 and 4) and it seemed also to decrease with concentration.

Table 4. Temora stylifera. Budget in nitrogen for individuals feeding on Hymenomonas elongata and Phaeodactylum tricornutum

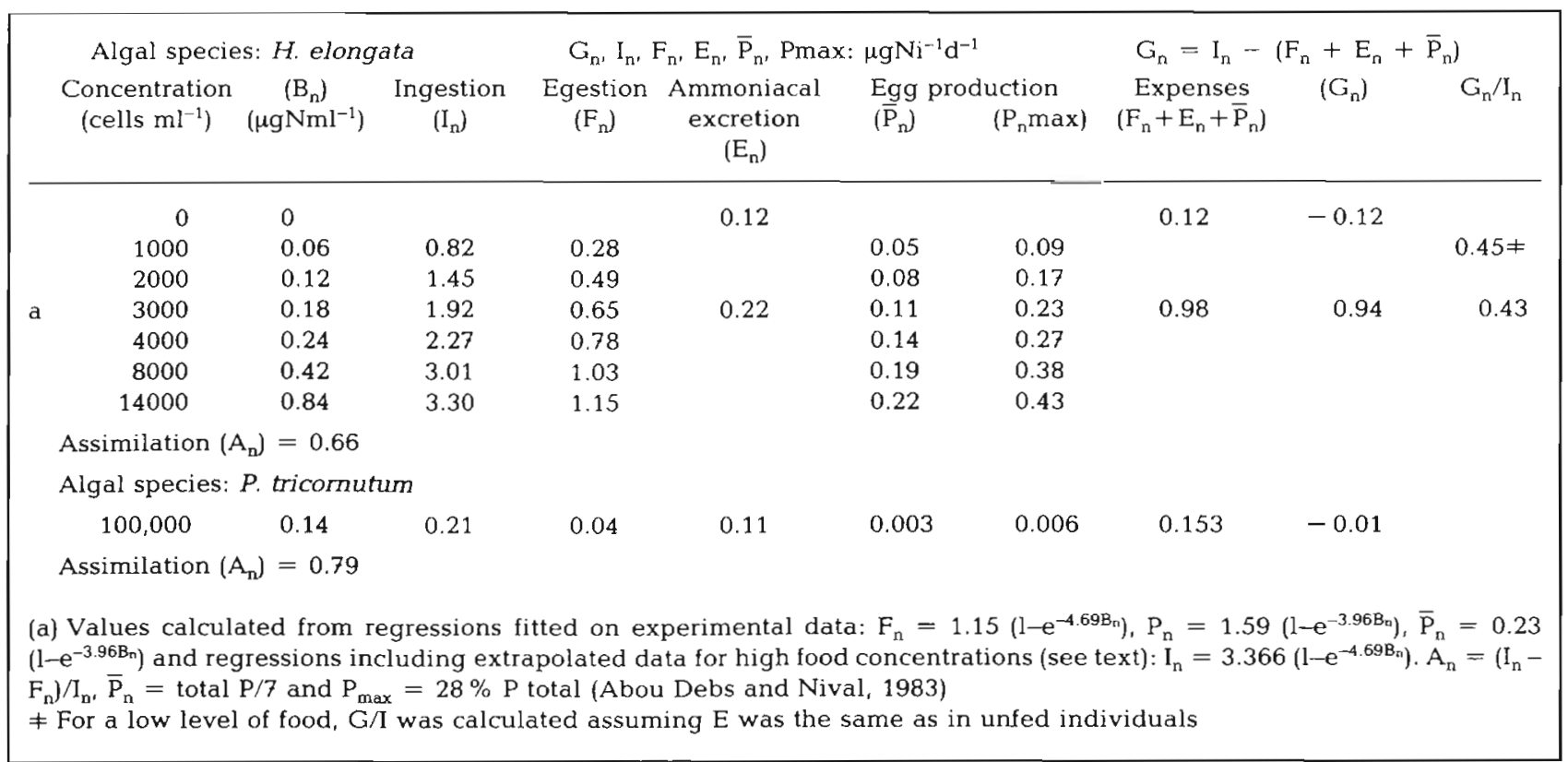




\section{DISCUSSION}

Daily ingestion rates of Temora stylifera feeding on Hymenomonas elongata were in the range of 10 to $185 \%$ of the $\mathrm{C}$ body weight of the adult. In our experimental range of $H$. elongata, saturation did not occur although it has been found at much lower concentrations such as $0.2 \mu \mathrm{g} \mathrm{C} \mathrm{ml} \mathrm{C}^{-1}$ of Thalassiosira with $T$. longicornis by Harris and Paffenhöfer (1976), $0.08 \mu \mathrm{g} \mathrm{N}$ $\mathrm{ml}^{-1}$ of Biddulphia with Calanus helgolandicus by Corner et al. (1972) or 50 to 200 cells $\mathrm{ml}^{-1}$ of Coscinodiscus with Calanus pacificus by Frost (1972). A linear relationship between ingestion rate and concentration of available food might be attributed to an adaptative mechanism in the digestive enzymes to the different food levels (Mayzaud and Poulet, 1978). Nonsaturated feeding has also been observed by Reeve and Walter (1977), Deason (1980) and Huntley (1981) for various species of copepods. Mayzaud and Poulet (1978) estimated that acclimation time was between $24 \mathrm{~h}$ and $6 \mathrm{~d}$; in this study, animals were acclimated to each food concentration $24 \mathrm{~h}$ before the measurements. However, in the theoretical model extrapolated for high concentrations of $H$. elongata, saturation was obtained at $16 \times 10^{3}$ cells $\mathrm{ml}^{-1}$ or $9.44 \mu \mathrm{g} \mathrm{C} \mathrm{ml} \mathrm{Cl}^{-1}$ and $0.82 \mu \mathrm{g} \mathrm{N} \mathrm{ml}^{-1}$. Robertson and Frost (1977) and Deason (1980) obtained also a maximal ingestion rate at relatively high concentrations. $10.10^{3}$ cells $\mathrm{ml}^{-1}$ of Thallassiosira fed to $C$. pacificus and 1 to $2 \mu \mathrm{g} \mathrm{C} \mathrm{ml}^{-1}$ of Skeletonema fed to Acartia hudsonica. Frost (1972), Robertson and Frost (1977) and $O^{\prime}$ Connors et al. (1980) found that the maximal ingestion rate and the critical concentration could vary with the composition, the amount of food available and the season. Expressed in volume, the theoretical ingestion concentration curve obtained here for $T$. stylifera is in the range of seasonal curves obtained for $T$. longicornis by $O^{\prime}$ Connors et al. (1980) and of the maximal ingestion rate $\left(44 \times 10^{6} \mu^{3}\right.$ $\mathrm{i}^{-1} \mathrm{~d}^{-1}$ ) given by the line plotted relating $\mathrm{I}_{\max }$ and the modal particle diameter which for $H$. elongata is $13 \mu \mathrm{m}$.

Assimilation rate was shown to be similar with either Phaeodactylum tricornutum or Hymenomonas elongata as food and was independent of its concentration. Similar conclusions were also made by Conover (1966) using the ratio method for Calanus finmarchicus and Harris (1973) for Tigriopus brevicornis. The mean value of $70 \%$ was in the range of assimilation rates generally accepted for other copepods (Conover, 1978).

The concentration of food available was correlated with the respiration, and, in our experimental range of concentrations, relation between food and metabolic activity could be described by an exponential model. At high concentrations, respiration rate was more than 20 times higher than the standard rate. By extrapola- tion, a maximal respiration rate was calculated at similarly high concentrations as was the maximum ingestion rate. The standard rate (i.e. ordinate-intercept), was also taken into account yielding a sigmoid shape model. Respiration rates measured on unfed and feeding Temora $\left(0.42\right.$ to $9.30 \mu \mathrm{l} \mathrm{O} \mathrm{O}_{2} \mathrm{mg}$ dry weight $\mathrm{h}^{-1}$ and mean adult dry weight, $26 \mu \mathrm{g}$ ) are within the range (1.6 to $15 \mu \mathrm{l}$ ) found for the same species by the authors listed by Fernandez (1978). Expressed in carbon, metabolic requirements ranged from $1.1 \%$ to $26.4 \%$ of the $\mathrm{C}$ body weight of Temora adults or from 7 to $10 \%$ of the carbon content of the Hymenomonas elongata ingested. These values, lower than the $20 \%$ obtained by Copping and Lorenzen (1980) for Calanus or the 15 to $30 \%$ obtained by Fernandez (1978) for $T$. stylifera, might be explained by the very high carbon content of $H$. elongata which yields high ingestion rates. Gaudy (1974) showed also an increase in respiration rate with food intake of $T$. stylifera, Calanus helgolandicus and Centropages typicus with a tendancy toward saturation followed again by an increase at very high ingestion rates $\left(100\right.$ to $\left.300 \mu \mathrm{g} \mathrm{d}^{-1}\right)$. Variability was very large and values were missing in the intermediate section. A more than 20 -fold increase in the respiration rate of the pteropod Clione limacina can be calculated under feeding conditions from an energy balance model by Conover and Lalli (1974). The relation between respiration rate and ingestion was assumed to be linear by Vidal (1980), following the theoretical model of Steele and Mullin (1977), so that respiration increased in a negatively accelerating manner parallelling the ingestion curve. An exponential respiration-ingestion model was used by Solomon and Brafield (1972) for fish, and saturation in both oxygen and food uptake was obtained for mussels by Thompson and Bayne (1974), Foster-Smith (1975) and Griffiths and King (1979). A sigmoid model and its parameters given here are defined for the first time for copepods. These results emphasize the importance of keeping the animals fed between and during the measurements rather than under starvation conditions to obtain more accurate estimates of the active metabolic expenses. Winberg's suggestion that the metabolism of fish feeding under natural conditions can be estimated as twice the standard metabolic rate (in Solomon and Brafield, 1972) has still to be confirmed, and that ratio seems low by comparison with our results and those listed here.

Most ammonia excretion rate estimates have been made for Calanus sp. The mean excretion rates by Temora stylifera, 4.14 and 8.78 , obtained with the 2 types of food were in the same range as those determined by Nival et al. (1974): 11.1 to $14.9 \mu \mathrm{g} \mathrm{N}$ (mg dry weight) ${ }^{-1} \mathrm{~h}^{-1}$, and by Fernandez (1978): 2.3 to 15.5 . Nival's values were somewhat higher. As in the case of 
respiration, this might be due to their low latitude upwelling sampling area where the copepods seemed to have higher metabolic activity.

An increase in excretion rate, probably caused by physiological stress during the first $2 \mathrm{~d}$, showed the necessity of an acclimation period to assess the effect of new nutritional conditions and that of long-term experiments where the animals are kept under feeding conditions. Similar observations were also made by Solomon and Brafield (1972) and Ikeda (1977). Takahashi and Ikeda (1975) and Nelson et al. (1979) have also shown the relation between excretion rate of small crustacea and concentration of food. A difference in ammonia excretion rate induced by different diets was shown by a 2 -fold increase obtained in the excretion rate of Temora stylifera feeding on Hymenomonas elongata, while excretion rate of Temora feeding on Phaeodactylum tricornutum was similar to that of the unfed individuals. Daily excretion rate varied then from 3.8 to $7.4 \%$ of the nitrogen body weight of the adult or from 11 to $12 \%$ of the nitrogen ingested in $H$. elongata. Diet influence on excretion rate was also shown for the shrimp Crangon crangon by Nelson et al. (1979). Low excretion with $P$. tricornutum was probably due to the small amount of nitrogen ingested when feeding on this algae. These results emphasize again the importance of feeding on metabolic activity such as excretion rates which could be underestimated by using animals starved before the experiments, as has been generally the case (Fernandez, 1978; Mayzaud, 1976). The role of zooplankton in the regeneration of nutrients for phytoplankton (Martin, 1968; Jawed, 1973; Smith and Whiteledge, 1977; Lehman, 1980) could be also underestimated, and the metabolic responses to the variations of food available to zooplankton could have a significant feedback on the phytoplankton.

Daily egg production (P/7) accounted for $6 \%$ in $\mathrm{C}$ and $7 \%$ in $\mathrm{N}$ of the ingested amount of Hymenomonas elongata. Its relation to food available was discussed in detail in Abou Debs and Nival (1983). Faecal pellet production accounted for 28 to $29 \%$ of the ingested carbon and 34 to $35 \%$ in nitrogen, and could constitute an important source of organic matter to the environment (Abou Debs, unpubl.).

The organic matter budget established here for Temora stylifera suggested that the $\mathrm{C}$ and $\mathrm{N}$ supplied by ingestion was much higher than the cost of metabolism, egestion and reproduction. A few possible reasons for this imbalance might be found: in adults, there should be no net growth and the apparent surplus of assimilated food, which in young stages goes into growth, must be otherwise accounted for. There could also be some overlooked fat synthesis. After $6 \mathrm{~d}$ in a concentration of $8.10^{3}$ cells $\mathrm{ml}^{-1}$ of Hymenomonas elongata, the lipid content of $T$. stylifera had increased from 11 to $15 \%$ over the initial dry weight (Abou Debs, 1979). Such storage, not usually observed in small wild copepods, might happen in well fed animals in the laboratory. Moreno et al. (1979) observed also a seasonal increase of the total lipid content of Paracalanus parvus over 2 to $7 \%$ of the dry weight, probably in response to the increase in phytoplankton available. Lipid storage was also observed in Eurytemora herdmani kept at low temperatures $\left(2^{\circ} \mathrm{C}\right)$ in running seawater (Abou Debs, unpubl.). However, this could be more a function of temperature than nutrition. Dissolved organic excretion, which was not measured here, could also explain a part of this difference. In addition certain benthic grazers have shown unbalanced budgets: in the sea urchin Strongylocentrotus droebachiensis 40 to $86 \%$ of the ingested food was attributed to organic excretion (Miller and Mann, 1973); in mollusc larvae, to some leakage in a soluble form (Pechenik, 1979); and 23 to $53 \%$ of the energy consumed by a population of the sea urchin Paraechinus angulosus remained unaccounted for (Greenwood, 1980). Copping and Lorenzen (1980) measured dissolved excretion of $27 \%$ of the carbon ingested by Calanus pacificus. Unbalanced budgets for insects and invertebrates were attributed to flask effects or effects of the experimental handling of the animals (Wightman, 1981). Based on the $C$ and $N$ content of the phytoplankton, ingestion rates could also have been overestimated: carbon content of $H$. elongata in our cultures were similar to the values obtained for the same species from Mullin et al. (1966), with a cell volume 3 times smaller, but our carbon values were 5 times higher than the values calculated from the carbon content - cellular volume regressions of Strathmann (1967), actually yielding 113 instead of $586 \mathrm{pg} \mathrm{C}$ cell $^{-1}$. Although using the smaller value leads to a reduction in the imbalance, there would still be an excess of ingestion.

The gain in carbon, ' $G$ ', calculated by difference between the amount of ingested carbon and that utilized in metabolism, reproduction and egestion seemed to decrease with increasing concentration of Hymenomonas elongata from $60 \%$ of the ingestion at $1.10^{3}$ cells $\mathrm{ml}^{-1}$ to $55 \%$ at $8.10^{3}$ cells $\mathrm{ml}^{-1}$. A larger sensibility of the budget equation to the variations of its parameters was also shown in the highest concentration range (Nival and Abou Debs, unpubl.). Medium concentrations of $H$. elongata seemed to give more reliable results, a larger scope for growth, a better survival and a similar reproduction rate as food in excess. But ingestion of Phaeodactylum tricornutum provided amounts of organic matter too small to cover the expenses of the budget and to allow reproduction and the animals behaved as if starved. As was also 
found by Epifanio et al. (1975) rearing bivalve larvae, this algal species, which has been often used in physiological and growth experiments, seems to be a poor food for Temora stylifera. Nitrogen deficiency seems to be part of the problem but some other chemical components might be missing, and they still have to be determined.

Acknowledgements. This research was supported by N.S.R.C. (Lebanon) and C.N.E.X.O. (France). I thank Dr P. Nival for his constructive suggestions during this work.

\section{LITERATURE CITED}

Abou Debs, C. (1979). Aspects de la physiologie et de la biologie de Temora stylifera Dana (copépode calanoide): éléments du bilan en carbone et en azote et optimisation de la fertilité. Thèse de $3^{\text {eme }}$ cycle, Université $P$. et $M$ Curie, Paris

Abou Debs, C., Nival, P. (1983). Etude de la ponte et du développement embryonnaire en relation avec la température et la nourriture chez Temora stylifera Dana (copepoda, calanoida). J. exp. mar. Biol. Ecol.

Conover, R. J. (1966). Factors affecting the assimilation of organic matter by zooplankton and the question of superfluous feeding. Limnol. Oceanogr II: 346-354

Conover, R. J. (1978). Transformation of organic matter In: Kinne, O, (ed.) Marine ecology, Vol. IV, Dynamics. Wiley, Chichester, p. 221-499

Conover, R. J., Lalli, C. M. (1974). Feeding and growth in Clione limacina a pteropod molusc. II: assimilation, metabolism and growth efficiency. J. exp. mar. Biol. Ecol. 16: $131-154$

Copping, A. E., Lorenzen, C. J. (1980). Carbon budget of a marine phytoplankton herbivore system with carbon 14 as a tracer. Limnol. Oceanogr. 25 (5): 873-882

Corner, E. D. S., Cowey, C. B., Marshall, S. M. (1967). On the nutrition and metabolism of zooplankton. $V$ : feeding efficiency of Calanus finnarchicus. J. mar. Biol. Ass. U. K. 47: $259-270$

Corner, E. D. S., Head, R. N., Kilvington, C. C. (1972). On the nutrition and metabolism of zooplankton. VII. The grazing of Biddulphia cells by Calanus helgolandicus. J. mar. biol. Ass. U. K. 52: $847-861$

Deason, E. E. (1980). Grazing of Acartia hudsonica (A. clausi) on Skeletonema costatum in Narragansett Bay (USA): influence of food concentration and temperature. Mar Biol. 60: 101-113

Elliott, J. M. (1976). The energetics of feeding, metabolism and growth of brown trout (salmo trutta L.) in relation to body weight, water temperature and ration size. J. Anim. Ecol. 45 (3): 925-948

Epifanio, C. E., Logan, C. Mootz, Turk, C. (1975). Culture of six species of bivalves in a recirculating seawater system. In: Persoone, G., Jaspers, E. (ed.) Proceedings of the 10th European Marine Biology Symposium, Vol. 1. Universa Press, Wetteren, p. 97-108

Fernandez, F. (1978). Metabolismo y alimentación en copepodos planctónicos del Mediterráneo: Respuesta a la temperatura. Investigación pesq. 42 (1): 97-139

Foster-Smith, R. L. (1975). The effects of concentration of suspension on the filtration rates and pseudofaecal production for Mytilus edulis L. Cerastoderma edule (L) and
Venerupis pullastra (Montagu). J. exp. mar. Biol. Ecol. 17 : $1-22$

Frost, B. W (1972). Effect of size and concentration of food particles on the feeding behavior of the marine planktonic Cop. Calanus pacificus. Limnol. Oceanogr $17(6)$ : $805-815$

Gaudy, R. (1974). Feeding four species of pelagic copepods under experimental conditions. Mar. Biol. 25 (2): 125-142

Greenwood, P.J. (1980). Growth, respiration and tentative energy budgets for two populations of the sea urchin Parechinus angulosus (Leske). Estuar. coast. mar. Sci. 10 (4): $347-368$

Griffiths, C. L., King, J. A. (1979). Some relationship between size, food availability and energy balance in the ribbed mussel Aulacomya ater. Mar. Biol. 51: 141-149

Hargis, J. R. (1977). Comparison of techniques for the measurement of zooplankton filtration rates. Limnol. Oceanogr. 22 (5): 942-945

Harris, R. P. (1973). Feeding, growth, reproduction and nitrogen utilization by the harpacticoid copepod Tigriopus brevicornis. J. mar. biol. Ass. U. K. 35: 785-800

Harris, R. P., Paffenhöfer, G. A. (1976). Feeding, growth and reproduction of the marine planktonic copepod Temora longicornis. J. mar. biol. Ass. U. K. 56: 675-690

Huntley, M. (1981). Nonselective, nonsaturated feeding by three calanoid copepods species in the Labrador Sea. Limnol. Oceanogr. 26 (5): 831-842

Ikeda, T. (1977). Feeding rates of planktonic copepods from a tropical sea. J. exp. mar. Biol. Ecol. 29 (3): 263-277

Jawed, M. (1973). Ammonia excretion by zooplankton and its significance to primary productivity during summer. Mar. Biol. 23: $115-120$

Lehmann, J. T (1980). Release and cycling of nutrients between planktonic algae and herbivores. Limnol. Oceanogr. 25 (4): 620-632

Martin, J. H. (1968). Phytoplankton relationships in Narragansett Bay. III. Seasonal changes in zooplankton excretion rates in relation to phytoplankton abundance. Limnol. Oceanogr. 13: 63-71

Mayzaud, P. (1976). Respiration and nitrogen excretion of zooplankton. IV. The influence of starvation on the metabolism and the biochemical composition of some species. Mar. Biol. 37: 47-58

Mayzaud, P., Poulet, S. A. (1978). The importance of the time factor in the response of zooplankton to varying concentration of naturally occurring particulate matter. Limnol. Oceanogr. 23 (6): 1144-1154

Miller, R. J., Mann, K. H. (1973). Ecological energetics of the seaweed zone in a marine bay on the Atlantic coast of Canada. J. Fish. Res. Bd Can. 28: 1733-1738

Moreno, V. J., de Moreno, J. E. A., Brenner, R. R. (1979). Lipid composition of Paracalanus parvus. Oceanologica Acta 2 (4): $373-378$

Mullin, M. M., Sloan, P. R., Eppley, R. W. (1966). Relationship between $C$ content cell volume and area in phytoplankton. Limnol. Oceanogr 11: 307-311

Mullin, M. M., Fuglister-Stewart, E., Fuglister, F. J. (1975). Ingestion by planctonic grazers as a function of concentration of food. Limnol. Oceanogs 20 (2): 259-262

Nassogne, A. (1970). Influence of food organisms on the development and culture of pelagic copepods. Helgoländer wiss. Meeresunters. 20: 333-345

Nelson, S. G., Simmons, M. A., Knight, A. W. (1979). Ammonia excretion by the benthic estuarine shrimp Crangon franciscorum (Crustacea: Crangonidae) in relation to diet. Mar. Biol. 54: 25-31

Nival, P., Corre, M. C. (1976). Variation annuelle des carac- 
téristiques hydrologiques de surface dans la rade de Villefranche-sur-mèr.. Ann. Inst. Oceanogr. 52 (1): 57-78

Nival, P., Mallara, G., Charra R., Palazolli, I., Nival, S. (1974). Etude de la respiration et de l'excrétion de quelques copépodes planctoniques (crustacea) dans la zone de remontée d'eau profonde des côtes Marocaines. J. exp. mar. Biol. Ecol. 15: 231-260

O'Connors, H. B., Biggs, D. C., Ninivaggi, D. V. (1980). Particle-size-dependent maximum grazing rates for Temora longicornis fed natural particles assemblages. Mar. Biol. 56 (1): $65-70$

Pechenik, J.A. (1979). Leakage of ingested carbon by gastropod larvae, and its effect on the calculation of assimilation efficiency. Estuaries 2 (1): 44-48

Provasoli, L. K. (1966). Media and prospects for cultivation of marine algae. Culture and collection of algae. In: Natanabe, A., Hahari, A. (ed.) Japanese Conference Hakano. Japanese Society Plant Physiology, p. 63-75

Provasoli, L. (1968). Media and prospects for the cultivation of marine algae. In: Watanabe, A., Hattori, A. (ed.) Cultures and collections of algae. Proceedings of US-Japan Conference, Hakone, 1966. Jap. Soc. Plant. Physiol., p. 63-75

Razouls, C. (1974). Variations annuelles quantitatives de deux espèces dominantes de copépodes planctoniques: Centropages typicus et Temora stylifera de la région de Banyuls. Cycles biologiques et estimation de la production. III Dynamique des populations et calcul de leur production. Cah. Biol. mar. 15 (1): 51-88

Reeve, M. R., Walter, M. A. (1977). Observations on the existence of lower threshold and upper critical food concentrations for the copepod Acartia tonsa Dana. J. exp. mar. Biol. Ecol 29 (3): 211-221

Robertson, S. B., Frost, B. W. (1977). Feeding by an omnivor- ous planktonic copepod Aerideus divergens Bradford. J. exp. mar. Biol. Ecol. 29 (3): 231-244

Sheldon, R. W. Parsons, T. R. (1967). A practical manual on the use of the Coulter Counter in marine research. Coulter Electronics, Toronto

Smith, S. L., Whitledge, T E. (1977). The role of zooplankton in the regeneration of nitrogen in a coastal upwelling system off Northwest Africa. Deep Sea Res. 24 (1): 49-56

Sokal, R. R., Rohlf, F. J. (1969). Biometry. W. H. Freeman and Company, San Francisco

Solomon, D. J., Brafield, A. E. (1972). The energetics of feeding, metabolism and growth of perch (Perca fluviatilis L.). J. Anim. Ecol. 41: 699-718

Steele, J. H., Mullin, M. M. (1977). Zooplankton dynamics. In: Goldberg, E. D., McCave, I. N., O'Brien, J. J., Steele, J. H. (ed.) The sea, Vol. 6. Wiley, New York, p. 857-889

Strathmann, R. R. (1967). Estimating the organic carbon content of phytoplankton from cell volume or plasma volume. Limnol. Oceanogr. 12: 411-418

Takahashi, M., Ikeda, T. (1975). Excretion of ammonia and inorganic phosphorus by Euphausia pacifica and Metridia pacifica at different concentrations of phytoplankton. J. Fish. Res. Bd Can. 32: 2189-2195

Thompson, R. J., Bayne, B. L. (1974). Some relationships between growth, metabolism and food in the mussel, Mytilus edulis. Mar Biol. 27: 317-326

Vidal, J. (1980). Physioecology of zooplankton. I: Effects of phytoplankton concentration, temperature and body size on the growth rate of Calanus pacificus and Pseudocalanus sp. Mar Biol. 56 (2): 111-134

Wightman, J. A. (1981). Why insect energy budgets do not balance. Oecologia (Berl.) 50: 166-169 